\title{
THE ISLAMIC DIALECTICS AND LOCAL CULTURE IN THE PETAWAREN TRADITION IN GAYO COMMUNITY
}

\author{
Marhamah Rusdy ${ }^{1}$ and Fauzi ${ }^{2}$ \\ ${ }^{1}$ IAIN Lhokseumawe, Aceh \\ ${ }^{2}$ Universitas Islam Kebangsaan Indonesia (UNIKI) Bireuen, Aceh \\ Email: marhamahrusdy@gmail.com
}

\section{Abstract}

This research aims to analyze the rituals or practices as well as traditional objects used in the Petawaren tradition of the Gayo community in Central Aceh District. This research employs descriptive research approach. The data needed are the ritual or implementation of Petawaren tradition and the traditional objects used, especially at a wedding or Ngerje ceremony. Primary data were obtained from research informants, namely traditional leaders, cultural figures, and community leaders, while secondary data are obtained from the relevant literature, documents, results of previous studies, and references. The techniques of collecting data are interview, observation, and documentation. This research also employs a relational dialectical theory. The results demonstrate that Petawaren tradition is purely Gayo culture, whereas the dialectics of Islam and Petawaren tradition in the Gayo community is more like accommodation of Islamic values. Therefore, the interpretation of the customary symbols, practices, and objects is eventually based on the Islamic teachings which replace the animistic beliefs existing before the arrival of Islam.

Penelitian ini bertujuan menganalisis ritual (amalan) serta benda-benda adat yang digunakan dalam pelaksanaan tradisi Petawaren masyarakat Gayo di Kabupaten Aceh Tengah. Penelitian ini merupakan penelitian deskriptif yang menerapkan pendekatan kualitatif. Data yang diperlukan berupa tata cara pelaksanaan serta benda-benda yang digunakan dalam tradisi Petawaren pada

el Harakah Jurnal Budaya Islam Vol. 22 No. 2 Tahun 2020 
upacara perkawinan Ngerje. Data utama bersumber dari informan penelitian, yaitu sesepuh (petue), tokoh adat, dan tokoh masyarakat. Sedangkan data sekunder diperoleh dari literatur, dokumen, hasil penelitian terdahulu, dan referensi yang relevan. Teknik pengumpulan data dilakukan dengan wawancara, pengamatan, dan dokumentasi. Penelitian ini menggunakan pendekatan teori dialektika relasional. Hasil penelitian menyimpulkan bahwa tradisi Petawaren adalah murni budaya Gayo, sedangkan dialektika Islam dan tradisi Petawaren pada masyarakat Gayo lebih kepada akomodasi nilai-nilai Islam. Oleh karena itu, pemaknaan terhadap simbol-simbol, ritual (amalan), dan benda-benda adat pada akhirnya didasarkan pada ajaran Islam, menggantikan kepercayaan animisme yang ada sebelum Islam datang.

Keywords: Dialectics; Gayo Community; Islam; Petawaren.

\section{Introduction}

Culture is a universal phenomenon with different forms from one society to another. Culture might be in the form of values and norms of the local culture known as local wisdom. Culture has characteristics that can be learned and exchanged so that it grows and develops (Liliweri, 2013). Culture is an orderly system of meanings and symbols, such as religion (Mardotillah \& Zein, 2016). As a system of values and symbols, religion and culture interact and influence each other. According to Kuntowijoyo (2001), religion influences culture in its formation, while culture can influence the system of values and symbols of religion. Likewise, with the presence of Islam, it does not erode the existing cultural values but there is a dialectic between the two.

The dialectics of Islamic teachings with local culture make it a religion that can touch all lifelines (Ilhami, 2010). The presence of Islam in a society does not necessarily erode the cultural values and traditions that have been formed, but instead, there is a dialectic between the two elements. Religion as a belief system contains moral values so that it constructs human behavior in their daily lives. Islam which can have dialectics with local culture proves its universality. The dialectics of Islam and local culture result in inculturation. Paisun (2010) states that inculturation presupposes a process of internalizing new teaching into the context of local culture in the form of accommodation or adaptation. This attitude reflects the ability to absorb the local culture a part of Islamic teachings. The Koran states that the traditions of previous people often become a foothold for people or the next generation (Asy-Syuara: 137). 
Dialectics between religion and culture can occur in several forms. First, religion influences culture in its formation. In other words, its value is religion, but its symbol is culture. Second, religion can influence religious symbols. Third, culture can replace the system of values and religious symbols. Religion without culture can indeed develop as a personal religion, but without culture, religion as a collectivity will have no place (Kuntowijoyo, 2001). In the dialectical process, Islam can be accommodated by local values. This is a characteristic of Islamic teachings, that is both accommodative and reformative of existing cultures and traditions without ignoring the purity of Islam itself.

Fauzi (2016) states that the community has its way to keep the local culture without harming the soul of Islam and to keep Islam is carried out while maintaining harmony in the traditions of the community. Religion and culture have their respective independence but have overlapping domains and occur continuously as a life-enriching process (Budiyanto, 2008). Islam and culture do not oppose each other but give each other the corridor of mutual acceptance which is deemed appropriate. Religion does not eliminate culture as long as it does not conflict with that religion. Religion as divine guidance was revealed to humans who have had culture (Poniman, 2015). While the culture is essential in the life of a society, as a society is however simple, still have a work culture, ethics, and taste. When religion comes to this locus there is a dialectics between the two. More specifically, when there is dialectics of religion (Islam) with the local culture (local wisdom), it will form a distinctive variant of Islam such as Islam Madura, Islamic Javanese, Malay Muslims, and soon. This variant does not mean that the religion has been deprived of its purity but it shows the dialectics of religion and culture.

The interaction of Islam and local culture is more dominant in the form of acculturation, both absorbing and dialogic (Muqoyyidin, 2013). Islamic acculturation patterns and local culture appear in the religious expression of the community, giving rise to a distinctive cultural character. Sumbulah (2012) stated that Javanese Islam has a character and a unique religious expression. This is because of the spread of Islam in Java, dominantly takes the form of acculturation, both absorbing and dialogical. The pattern of Islam and Javanese acculturation which can be seen on the expression of the Java community is also supported by the political power of the Islamic kingdom of Java. especially Mataram which had brought Islam to the Javanese cosmology of Hinduism and Buddhism.

el Harakah Jurnal Budaya Islam Vol. 22 No. 2 Tahun 2020 
The dialectics between Islam and local culture in society experiences various forms of relationship depending on the community's appreciation toward Islamic teachings itself. Gayo community is one of the Acehnese ethnics who is classified into relatives of Proto Melayu or Old Malay who came from the Dutch East Indies to the archipelago in the first wave before Christ (Ibrahim, 2007). Gayo region includes Bener Meriah, Central Aceh, Gayo Lues districts, as well as parts of Southeast Aceh, Aceh Tamiang, and East Aceh (Melalatoa, 2006). Gayo community has a culture that is still strongly bonded to various values and norms. Gayo's cultural value system is divided into the main value and supporting values. The main value in Gayo culture is called mukemel (self-esteem), and to achieve that self-esteem, someone must practice it and hold on to several supporting values (Ibrahim, 2010). These cultural values become the ideal concept of character formation and a guide for the pattern of community action. Thus, these cultural values reflect the profile of the Gayo community and they become an important foundation in forming individuals who are respected in social relationships.

The majority of Gayo people are Muslims and are known for their obedience to religion while still upholding culture (Marhamah, 2014). Acculturation between Gayo customs and Islamic law is very close and mutually supportive. Custom functions to support the implementation of Islamic teachings as a cultural principle in the life of the Gayo community. Customs as socio-cultural values and beliefs have been rooted in the life of the Gayo community, as explained through the expression: ukum orom edet; lagu zet orom sipet, which means Islam and Gayo customs are like substances which cannot be separated.

One of the cultures maintained by Gayo community is Petawaren tradition. It is the ritual of offering something or someone as a symbol of requests for salvation, peace, happiness. and blessings from Allah (Ibrahim, 2010). Petawaren acts as an expression of gratitude to God symbolized by rice and paddy because the Gayo ethnic life has always been agrarian (Pinan, 2003). This tradition is a relic of animistic beliefs maintained today. The presence of Islam and acculturation with Gayo culture influenced the rituals and the objects used in Petawaren tradition. As a form of local wisdom, it must continue to be preserved and one of the ways to preserve them is through scientific studies. This research is focused on the implementation or rituals of Petawaren tradition after acculturation with Islam; and the customary objects that are used in the rituals of Petawaren tradition after acculturation with Islam. 
Studies on the dialectics of Islam and culture explain that Islamic acculturation and Gayo culture are more dominant in the Islamic Gayonization approach than the Gayo Islamization approach. In the Islamic Gayonization approach, the objects and equipment used in rituals are purely Gayo culture by inserting the values of Islamic teachings (Mustafa and Hidayat, 2017). Another study explains that Islam is easily accepted by Gayo people who were initially adherents of animism. Besides, the support of sarakopat as opinion leaders increasingly facilitates and strengthens the inclusion of Islam in all aspects of Gayo community life (Mustafa, 2017).

Marzuki (2011) also conducted a study revealing that Peusijuek is one of the Islamic cultures that is still preserved and becomes an official ritual for several people in Aceh. Peusijuek is believed by Acehnese people as one of the rituals associated with belief in religion because Peusijuek is full of religious values. The important element in Peusijuek is that the implementer should be someone who understands religion, religious and cultural activities such as marriage, circumcision, going pilgrimage, and others, as well as can lead the praying according to the Koran and the Sunnah. This current research is different from those previous researches because the main aspects examined are the ritual or implementation and the traditional objects used in Petawaren tradition after the dialectics/acculturation with Islam.

Riezal et al., (2018) also elaborated on the same topic showing that according to the historical records, the implementation of Peusijuek tradition before the arrival of Islam still uses certain mantras and prayers. However, since the arrival and development of Islam in Aceh, Peusijuek tradition has changed by incorporating Islamic teachings in it, such as prayer, and other Islamic teachings. That is why Peusijuek tradition in Aceh might still be preserved up to now. In practice, Peusijuek tradition is carried out by religious leaders and elders of Aceh, such as ulama, Tengku, Ustaz, and Ustazah. This is done because Peusijuek tradition is considered a sacred Acehnese procession. The practice of Peusijuek tradition in Aceh is carried out in religious and cultural activities, such as going pilgrimage, marriage, circumcision, prayer, arena, buying new vehicles, and so forth. The purpose of Peusijuek tradition is to appeal for the satisfaction, peace, happiness, and glory of the guests.

Another research on the tradition has been conducted by Noviana (2018). She explained that culture is a dynamic process and has the values and norms of life applied in certain social relations procedures. From this culture, a variety of community habits are created, including regional languages, dance, 
music, and traditional ceremonies. All of these habits are the result of the cultural part. Peusijuek contains very philosophical religious values so that it is considered very sacred and must be carried out in activities that are believed to Peusijuek. This tradition is one of the traditions of Acehnese people who have been assimilated with Islamic teachings. Therefore, it is still maintained today. Among the elements that have been changed are the mantras used in Peusijuek procession which have been replaced with Arabic-language prayers. In the implementation of this Peusijuek, there are three most important things, namely, the device and the material for Peusijuek, movements or steps, and prayers.

\section{Method}

The method used in this research is qualitative. This method can describe systematically, factually, and accurately the interrelated facts contained in Petawaren tradition (Nazir, 2011). Since the data needed in this research are descriptive, researchers emphasize factual research related to rituals or practices and traditional objects used in the Petawaren tradition.

The research location is in Central Aceh Regency. The data sources consist of primary data and secondary data. Primary data collected are focused on phenomena related to the object of research, namely rituals or practices and objects that are used in Petawaren tradition, especially at wedding ceremonies or Ngerje. While secondary data are obtained from the literature, documents, results of previous studies, and references that are relevant to this research.

Data collection techniques are ways that researchers use to obtain and collect the data needed to answer research problems (Nazir, 2011). Data collection techniques used are in-depth interviews, observations, and documentation. To get the information needed, the researchers then determined key informants with criteria as follows: 1). People who understand about Gayo culture in Central Aceh District; and 2). People who understand Petawaren tradition in Central Aceh District. There are six informants in this research consisting of traditional leaders, cultural figures, and community leaders.

Meanwhile, to see the truth of the data, the researchers employed triangulation techniques. Triangulation is a data checking technique that uses something else in comparing the results of interviews with research objects (Sugiyono, 2019). The researchers cross-check data among the informants determined in the field. They compare data from informants with observations and study documents (on books and other literature). 
Data analysis was carried out as well in this research. The collected data were analyzed using descriptive analysis techniques. The flow of analysis includes data reduction, data presentation, and conclusions drawn simultaneously. Data analysis in this research is in the form of a process of organizing, grouping, categorizing, and then giving meaning to each category that has been classified.

\section{Theory of Relational Dialectics}

The paradigm developed in this research is Islamic dialectics and Gayo culture which can be explained through relational dialectics theory. The theory of relational dialectics was formulated by Baxter (2006), in the book relating to dialogues and dialectics. For several years, Baxter studied the ideas of Mikhail Bakhtin, a Russian philosopher (personal dialogue theory), about dialogue as a way to better understand the fluctuations in relations between individuals. But at the same time, Baxter also explained that his theory is dialectical, meaning that a relationship is a place where various disagreements or debates (contradictions) are managed or regulated.

Defined communication patterns between partner is a result of endemic dialectical tensions. It shows that life is related to tensions or conflicts between individuals. The conflict occurs when someone tries to impose their desires on one another. People cannot always resolve contradictory elements in their beliefs and they have inconsistent beliefs about relationships (West et al., 2017). In other words, relationships have a dynamic nature, and communication is basically how people manage similarities and differences. Communication also leads us together towards similarity, but communication also creates, maintains, and manages differences.

The theory of relational dialectics in reflecting arguments about life relates to four basic assumptions. The first assumption states that relationships are not linear. The most important assumption underlying this theory is the thought that relationships do not consist of linear parts. On the contrary, the relationship consists of fluctuations that occur between contradictory desires. Second, it is characterized by a change. This assumption proposes the thinking about a process or change although it does not fully frame this process as linear progress. The process or change of a relationship refers to quantitative and qualitative movements over time and the contradictions that occur, around which a relationship is managed. Third, the contradiction is a fundamental fact in a relationship. Fourth, this third assumption emphasizes that the contradictions or tensions that occur between two opposing things 
never disappear and never stop creating tension. Humans manage this tension and opposition in different ways, but this always exists in a relationship. The attraction and encouragement presented by dialectics construct the relationship and the function of communication itself is to manage those tensions. The final assumption is that communication is very important in managing and negotiating contradictions in relationships. Individuals communicate with one another to manage and resolve any contradiction in their relationships. Contradictions in social interaction emerged due to human communication among individuals. For instance, when one tries to build up a relationship with another person, he/she should discuss or communicate it with their couple. Thus, if a conflict occurs, they might manage and resolve the conflict by communicating and discussing the problems so that their relationship will be fine and long-lasting. They both might open up to each other as well (West et al., 2017).

\section{Islamic Values Reflected in the Implementation of Petawaren Tradition in Gayo Community}

The findings demonstrate that some Islamic values accommodated in Petawaren tradition. The rituals in Petaweran tradition are then defined based on Islamic teachings. Thus, these cultural rites not only appear to be cultural symbols but also reveal the Islamic values believed by the performer. In other words, symbolic meaning is expressed through the symbols depicted on the surface and behind the tradition.

Petawaren tradition in the Gayo community becomes customary tradition conducted in various activities such as weddings, setting up new houses, opening paddy fields or gardens, wandering, circumcision, making peace due to fights, going on pilgrimage, and so on. Petawaren tradition contains religious values and cultural values through the symbols used in the ceremony. Before the arrival of Islam, Petawaren tradition was part of animistic beliefs. Gayo people had animistic beliefs before the arrival of Islam. This is proven by the discovery of the site by an archeologist from Medan Archeology Agency named Ketut Wiradnyana.

The discovery of the Ujung Karang site in Kebangkan District, Central Aceh, proves the existence of a cemetery (tomb) in which it is equipped with the burial provisions in the form of a clay container, stone arrowheads, and also a woven container. The existence of the tomb illustrates people's belief in 
the existence of the hereafter. Therefore, the body was equipped with burial provisions so that their way to another realm is not disturbed (Ibrahim, 2007).

The archeological findings show that before Islam entered the Gayo region, Gayo people still hold animism. When Islam entered Perlak and developed rapidly in the first century of Hijriyah, animism believed by the Gayo people gradually disappeared and turned to Islamic beliefs. The animistic beliefs they believed in and the customs they had held for generations from centuries before Islam, were gradually changed and adjusted to the values and norms of Islamic teachings (Ibrahim, 2010).

In the pre-Islamic era, the tradition of marriage was intended to keep away the evil spirits causing disaster. After Islam entered, the tradition was intended to ask Allah for salvation, peace, and happiness. In a cultural sense, Petawaren is intended to advise a person or group of people. Petawaren tradition at a wedding ceremony or Ngerje is performed at both traditional ceremonies and Mah Bai event. The ceremony is usually carried out by advising the prospective bride about the main points of faith, responsibilities in the family, and community life. Mah Bai event is intended to take the groom to the bride's house (interview with M. Yusin Saleh, Gayo traditional figure).

Through the observation conducted by the researchers, it shows that the traditional Berguru ceremony is usually done at night after the evening prayer before the wedding. It is considered a good time since it is a time shift from day to night. That time is usually used to gather with the family after working in the fields as well. Parents of the bride and groom invite Sarakopat, namely Imem, Reje, Tengku, or the elder to advise the bride and groom.

The researchers also observed that the implementation or ritual of Petawaren tradition begins with the bride sitting on a small mat (ampang) which is only used in certain traditional activities, then covered with a cloth called ules ulen-ulen. While the way to sit is different between men and women. The way to sit for men is besile or semile (cross-legged), while the way to sit for women is by flapping, which is sitting crossing on both folds of her legs like tahayyat when praying. Each of the bride and groom's hands is held together facing openly with the right hand on top and the left hand under the right hand.

The ritual begins with reciting prayers lead by the one who understands the procedures and prayers called Imem or Tengku. After reciting the prayer, the plants are tied into an object in the form of small clay pots or pottery filled with water to soak the plants. The next step is to take the wet roots of the plants soaked in Petawaren water to touch it to the palms of the bride's 
hand. This is done by moving the plant ties so that the water in the root can wet the hand completely. Next, they wet the bride's shoulder three times a row with Petawaren water. After completing this section, Imem or Tengku takes a small handful of rice while praying. Then the rice is placed on the palm, the left shoulders, and slightly above the head. This is done three times in a row as well. And finally, the bride's two hands are raised above the head that has been spiked with rice earlier (interview with Alam Syuhada, community leader of Gayo).

The procedures of implementing the Peusijuek tradition are also carried out in several sequences. The first is sprinkling rice (breuh padee), the second is sprinkle water with fresh flour, third edit glutinous rice (bu leukat) on the right ear and the last is giving money (teumutuek). These procedures are generally almost the same for each procession of Peusijuek Aceh tradition. However, there are several differences according to the activities held inside the Peusijuek (Dhuhri, 2008). As the research conducted by Riezal, Chaerol, Hermanu Joebagio (2018), The Peusijuek tradition is a culture of Acehnese people associated with Islam, because Peusijuek tradition has religious values, and have an Islamic nuance put into practice. This can be seen from the elements of Peusijuek tradition that comprise of three things, namely first, the leader of the implementation of Peusijuek tradition is carried out by scholars, Tengku, ustaz, and ustazah, who understands Islam, and Acehnese culture. Second, the implementation of Peusijuek traditions is done when there is an event of children's aqiqah, marriage, going pilgrimage, circumcision, and so on. Third, the prayers that are recited in this Peusijuek tradition is a prayer addressed to Allah and the Prophet Muhammad.

The rituals in Petawaren tradition are symbolized as safety, happiness, harmony, coolness, in wading through domestic life, so does the ritual tradition of Petawaren in other activities. Therefore, the ritual or implementation of Petawaren tradition must begin with reciting the prayer. In animistic beliefs, the ritual begins with chanting to ask spirits for help. This understanding is based on the belief that these spirits can keep away disaster and bring happiness. The accommodation of cultural rites with Islam is evident in the replacement of mantras with prayers that reflect the moment of activity. Hopefully, it is always intended to get protection and blessing from God. Sitting on ampang shows obedience to the applicable rules and humility. Whereas the sprinkling of water and rice shows the meaning of holy and clean. Bringing both hands together with the right hand on the left palm gives the meaning of being 
ready to accept responsibility. And the ties of plants that are touched and rice placed on both hands means that the person will be given salvation and protection from God. The final step of lifting the hands fulfilled with rice above the head symbolizes as gaining glory and respect from the community and environment (interview with Tgk. Abdullah. HR, Gayo traditional figure)

\section{The Islamic Values of Customary Objects in Petawaren Tradition of Gayo Community}

The implementation of Petawaren tradition uses objects as traditional equipment in the traditional ceremonial procession. The meaning of the traditional objects is associated with Islam and emerges the symbols that have an Islamic nuance. The materials used in Petawaren tradition are dedingin or cocor bebek (Kalanchoe pinnata), celala or spinach (Coleus sp), firm stems or starlings (Dactyloctenium aegyptium), sesampe or gegunjuran grass (Paspalum commersonii sangiunalisalis), bebesi which is a kind of small leafy plants living in hedges or moringa leaves (Moringaoleifera), cul wood or large wood buds, cool or cold water, oros or rice, and gold (interview with Tgk Anwar, public figure).

Plant material is put in the book or pottery that has been filled with water with its roots down. Rice is put in a tape or bag in the form of small chopsticks. Dedingin or cocor bebek (Kalanchoe pinnata) and celala or spinach (Coleus sp) plants are interpreted as symbols of life and fortune. Starling and firm stem are the symbol of solidity in holding principles as well as upholding religious and customary rules. The wood pucuk nikul is meant as a symbol of protection from various disasters. While bebesi plants are interpreted as strong physical and mental symbols in carrying out life. The symbol of water is fertility, and the symbol of rice is sustenance, and gold and silver are symbolized as purity, happiness, and greatness. In the belief of animism, the plant is believed to be able to help ward off evil spirits (interview with Ibrahim Kader, cultural figure).

Each of those leaves is an antidote in running the ark of life, like taking decisions deliberately, being fully responsible, and being able to forge a close relationship with anyone. And the meaning of the strap from all these devices is for uniting the people in Petawaren so that they can be friends with anyone and always have a harmonious relationship. Another traditional object used in Petawaren tradition is the cloth called upuh ulen-ulen which symbolizes Islamic values. Ulen-ulen wages are rectangular long cloths with the motif of the moon or the shape of circles. The basic colors of the cloth are 4 (four) symbols of opat or four elements in the social order of the Gayo community. The yellow 
symbolizes gold, the representation of the reje (king) group as the first aspect of the opat sect. The red symbolizes the courage to show the identity of the petue (traditional elders). The white color is the identity of the imem (religious leader) which symbolizes purity and wisdom in sorting between good and bad. The green color symbolizes reyet (ordinary people) which is interpreted as a message to live in consultation and hope for fertility. The four colors are based on black as a symbol of land or earth where humans are created and will return (interview with M. Yusin Saleh, traditional leader).

Upuh ulen-ulen is a long garment or cloth which is a symbol of greatness and respect for the customs of the Gayo community, as well as the philosophy of life of Gayo people. It is referenced to Gayo Kerawang carving and embroidery (Herawati, 2011). The Gayo Kerawang motif structure is formed from an arrangement of elements in the form of lines, tone, color, and shape. The strength of the meaning of this motif is supported by the element of art such as color and tone. In general, four colors are standing out in society which is yellow, green, white, and red combined with black. The yellow color means musuket sifet (full of consideration) which is symbolized to the kingdom. In this case, the king is associated with government leaders such as the head of regency, district, and village, who has the authority to protect its people.

The red color symbolizes the nature of musidik sasat which means full courage in upholding the truth. The white color symbolizes the need for sunet namely the ability to distinguish between good and bad, and holiness. Green color (green) means even consensus (deliberation). Besides, the basic color commonly used is black which symbolizes the earth. The application of the Gayo openwork motif on upuh ulen-ulen is arranged based on the arrangement of harmonious blend. The placement of each motif that is applied is adjusted to the form and condition of the field so that there are times when one type of motif is present in some repeating colors. Each decorated area always uses the same motif components, namely, emun berangkat. This motif is not a full circle, but a motive in the form of a curved line, towards a center point of the circle.

Ulen-ulen cloth has several motifs in it, which are peger motif, teikukur, bunge kipes, puter tali, and pucuk rebung. These motifs are connoted as culture and the rule of law in the Gayo area. The motifs are used generally in the forms of plants and other natural objects but have never been used as the motives of living things which in Gayo culture are considered taboo. The motifs on ules ulen-ulen connotatively describe the natural state of the Gayo land. Like the fence motifs, the fence is connoted as a symbol of the fertility of Gayo 
land. Bamboo sprouts are a type of shrub that grows in the Gayo area. This plant has many benefits. Besides being a vegetable, it can also be processed into household handicraft items such as chairs and so on.

Emun berangkat, this motif is a symbol of the hope that humans can navigate the trials of life in the world. Puter tali, this motif describes the sturdiness in unity. Tapak seleman emphasizes that in the life of the Gayo people four elements overshadow the customary system and the government known as sarakopat. The four elements are reje musuket sipet (the king must be fair), petue musidik sakat (petue is a court officer), imem muperlu sunet (the priest must know what is obligatory and what is circumcision), and rayat genap mupakat (people must be in line with what has been agreed).

The pattern of the pucuk rebung is a pyramid or triangle. In the philosophy of the Gayo community, pucuk rebung has essence values in the form of hope that the Gayo community must be firm, strong have faith and piety, are humble, and have good character. Peger, as the name implies, the placement of the fence motif is the boundary between one motif with other motives. For the Gayo community, the Peger motif is a symbol of defense and order social community. Usually, this fence motif is located on the dividing wall at each of the five basic motives. This upuh ulen-ulen is a characteristic of the Gayo community. The motif of carving shows the strength of the unity and integrity existing in the Gayo community. The motives for upuh ulen-ulen provide a lot of information, advice, and teachings to society, and is a rule that can guide humans to become better individuals in this world, especially in society. The motives of upuh ulen-ulen can be considered as a cultural heritage and identity of the Gayo community that must be preserved (Fitri, 2020).

Puter tali motif is connoted as a symbol of unity of each division member. The principle of unity and togetherness is the basic nature of the Gayo ethnic group. The teikukur motif is connoted as prosperity and well-being. Many turtles live in the Gayo area, and often roam, especially during the coffee season, and eat them, so the corals will grow back into plants elsewhere. Symbols of honor and dignity are connoted with bunge kipes motifs. The motif is connoted as strength and defense which was an attempt by Gayo ethnic groups to resist the influence of outside cultures that could damage Gayo culture and customs (interview with Joni, Gayo traditional figure). Thus, ulen-ulen or moon is interpreted as the greatness of the Creator and the gift given, namely the religion of Islam. In Gayo culture, Islam is seen as the direction or the moon 
illuminating the darkness at night. In sum, Gayo culture clothing gives humans an identity, position, and honor.

\section{Conclusion}

Petawaren tradition is purely Gayo culture, while the dialectics of Islam and Petawaren tradition in the Gayo community are more like accommodation of Islamic values. Islamic values are embedded in rituals or practices, and customary objects or equipment used in Petawaren tradition to replace the teaching of animistic beliefs existing before the arrival of Islam. The rituals in Petaweran tradition are then defined based on Islamic teachings. Thus, the cultural rites appear to be cultural symbols and reveal the Islamic values believed by the Gayo community. Moreover, the Gayo community has a philosophy, namely: ukum orom edet; lagu zet orom sipet, which means Islam and Gayo customs are like substances which cannot be separated.

\section{References}

Baxter, L. A. 2006. Relational Dialectics Theory: Multivocal Dialogues of Family Communication. Engaging Theories in Family Communication: Multiple Perspectives. SAGE Publications, Inc. https://doi.org/http:// dx.doi.org/10.4135/9781452204420.n9.

Budiyanto, M. 2008. Pergulatan Agama dan Budaya“. Jurnal Penelitian Agama, 17(3), 649-668. http://digilib.uin-suka.ac.id/id/eprint/8816.

Dhuhri, S. 2008. Peusjuek: Sebuah Tradisi Ritual Sosial Masyarakat Pasee dalam Perspektif Tradisionalis dan Reformis. The 3rd International Conference On Development of Aceh (ICDA-), 639-656.

Fauzi. 2016. Interaksi Islam dengan Budaya Lokal dalam Tradisi Khanduri Maulod pada Masyarakat Aceh. Akademika, 21(1), 19-34. http://e-journal. metrouniv.ac.id/index.php/akademika/article/view/453.

Fitri, R. 2020. Makna dan Fungsi Motif Kerawang Gayo pada Upuh Ulen-Ulen di Kecamatan Kebayakan Kabupaten Aceh Tengah. Seminar Nasional Pendidikan Antropologi (SENASPA), 101-106. https://senaspa.unimed. ac.id/wp-content/uploads/2020/03/10-RITA-FITRI-101-106.pdf.

Herawati, T. Z. 2011. Buku Ajar Tradisional Aceh. Fkip Pkk Unsyiah.

Ibrahim, M. 2007. Mujahid Dataran Tinggi Gayo. Yayasan Maqamammahmuda. 
Ibrahim, M. 2010. Syariat dan Adat Gayo (2nd ed.). Yayasan Maqamammahmudah.

Ilhami, H. 2010. Dinamika Islam Tradisional: Potret Praktek Keagamaan Umat Islam Banjarmasin pada Bulan Ramadhan. Jurnal Darussalam, 11(2), 69-88. https://adoc.tips/dinamika-islam-tradisional-potret-praktikkeagamaan-umat-isl.html

Kuntowijoyo. 2001. Muslim tanpa Mesjid: Essai-essai Agama, Budaya dan Politik dalam Bingkai Strukturalisme, Transendental. Mizan.

Liliweri, A. 2013. Makna Budaya dalam Komunikasi Antar Budaya. LKIS. http:// www.lkis.co.id/produk-830-maknabudayadalamkomunikasiantarbud aya.html.

Mardotillah. M \& Zein, D. M. 2016. Silat: Identitas Budaya, Pendidikan, Seni Bela Diri, dan Pemeliharaan Kesehatan. JANTRO, 18(2), 121-133. https://doi.org/10.25077/jantro.v18.n2.p121-133.2016.

Marhamah. 2014. Pola Komunikasi dan Stratafikasi dalam Budaya Tutur Masyarakat Gayo. El Harakah, 16(2), 255-270. https://doi.org/10.18860/ el.v16i2.2779.

Marzuki. 2011. Tradisi Peusijuek dalam Masyarakat Aceh: Integritas Nilai-nilai Agama dan Budaya. ElHarakah, 13(2), 133-149. https://doi.org/https:// doi.org/10.18860/el.v0i0.458.

Melalatoa, M. J. 2006. Memahami Aceh Sebuah Perspektif Budaya dalam Aceh, Kembali ke Masa Depan. IKJ Press.

Muqoyyidin, A. W. 2013. Dialektika Islam dan Budaya Lokal Jawa. Ibda', Jurnal Kajian Islam Dan Budaya, 11(1), 1-18. https://doi.org/https:// doi.org/10.24090/ibda.v11i1.

Mustafa, A. 2017. Dakwah Kultural di Tanoh Gayo. At Tanzir, Jurnal Komunikasi dan Penyiaran Islam, 8(2), 175-182. https://ejournal.staindirundeng. ac.id/index.php/tanzir/article/download/75/54/.

Mustafa, A. \& Hidayat, R. 2017. Islam Gayo: Studi tentang Akulturasi Islam dengan Budaya Lokal di Kabupaten Aceh Tengah. Al Misbah, 13(2), 313-334. https://almishbahjurnal.com/index.php/al-mishbah/article/ view/90/86

el Harakah Jurnal Budaya Islam Vol. 22 No. 2 Tahun 2020 
Nazir, M. 2011. Metode Penelitian. Ghalia Indonesia.

Noviana, N. 2018. Integritas Kearifan Lokal Budaya Masyarakat Aceh dalam Tradisi Peusijuk. Jurnal Deskovi, 1(1), 29-34. https://e-journal.umaha. ac.id/index.php/deskovi/article/view/283

Paisun. 2010. Dinamika Islam Kultural: Studi atas Dialektika Islam dan Budaya Lokal Madura. ElHarakah, 12(2), 154-168. https://doi.org/https://doi. org/10.18860/el.v0i0.450

Pinan, A. H. 2003. Pesona Tanoh Gayo. Pemerintah Kabupaten Aceh Tengah.

Poniman. 2015. Dialektika Agama dan Budaya. Nuansa, Jurnal Islam Dan Kemasyarakatan, 8(2), 165-171. https://doi.org/http://dx.doi. org/10.29300/nuansa.v8i2.394.

Riezal, Chaerol, Hermanu Joebagio, S. 2018. Konstruksi Makna Tradisi Peusijuek dalam Budaya Aceh. Jurnal Antropologi: Isu-Isu Sosial Budaya, 2-(2), 145-155. https://doi.org/https://doi.org/10.25077/jantro.v20. n2.p145-155.2018.

Sugiyono. 2019. Metode Penelitian Kuantitatif, Kualitatif, dan REDD. Alfabeta. http://cvalfabeta.com/product/metode-penelitian-kuantitatif-kualitatifdan-rd-mpkk/.

Sumbulah, U. 2012. Islam Jawa dan Akulturasi Budaya: Karakteristik, Variasi dan Ketaatan Ekspresif. El Harakah, 14(1), 51-68. https://doi. org/10.18860/el.v0i0.2191.

West, R. \& Turner, L. H. 2017. Pengantar Teori Komunikasi: Analisis dan Aplikasi (5th ed.). Salemba Humanika. 